\title{
Article
}

http://dx.doi.org/10.11646/phytotaxa.173.4.1

\section{Molecular phylogenetics and morphology support two new genera (Memoremea and Nihon) of Boraginaceae s.s.}

\author{
ANA OTERO ${ }^{1,2}$, PEDRO JIMÉNEZ-MEJÍAS ${ }^{1}$, VIRGINIA VALCÁRCEL ${ }^{2} \&$ PABLO VARGAS ${ }^{1}$ \\ ${ }^{I}$ Dpto. de Biodiversidad y Conservación. Real Jardín Botánico (RJB-CSIC). Plaza de Murillo 2. 28014 Madrid. España \\ (anaoterogomez@gmail.com). \\ ${ }^{2}$ Dpto. de Biología (Botánica). Universidad Autónoma de Madrid. Campus de Cantoblanco. C/ Darwin 2. 28049 Madrid. España.
}

\begin{abstract}
Omphalodes (Boraginaceae s.s., Cynoglosseae s.1.) comprises ca. 29 species of annual and perennial plants distributed in three main disjunct areas: Western Palearctic, Japan and SW of North America. This paper uses micromorphological and DNA data to re-assess the monophyly and taxonomy of the genus. Morphological characters of 15 species of Omphalodes and four closely-related genera were analysed using SEM. A total of 82 ITS and $68 \operatorname{trn} \mathrm{L}-\operatorname{trn} \mathrm{F}$ sequences were newly sequenced, including 14 species of Omphalodes and three genera of the tribe Cynoglosseae. Phylogenetic analyses of 57 genera (186 species) of Boraginaceae indicated that Omphalodes as currently circumscribed is formed by three independent lineages, which were supported by morphological characters of the fruit. As a result, and in the interest of a more natural classification, two new genera are described to accommodate Omphalodes scorpioides (Memoremea) from Europe and the Japanese species (Nihon). Memoremea is distinguished from all the other species previously included in Omphalodes by the apical attachment scar and the hollow nutlet margin. Nihon is easily discriminated by the abrupt change of margin ornamentation towards the nutlet aperture. We also provided a taxonomic treatment that proposes the lowest number of nomenclature changes, although six new combinations are required.
\end{abstract}

Key words: Carpology, DNA sequences, Scanning Electron Microscopy, Systematics

\section{Introduction}

Boraginaceae s.s. (=Boraginaceae subfam. Boraginoideae; Al-Shehbaz, 1991; Gürke, 1893) comprises 112 genera and about 1600 species (Stevens 2001 onwards) of herbaceous plants and shrubs. Between four and 13 tribes have been traditionally recognized within the Boraginaceae s.s. based on morphological characters (De Candolle 1846, Baillon 1890, Gürke 1893, Johnston 1924, Popov 1953, Al-Shehbaz 1991, Riedl 1997). Nutlet macromorphology has traditionally been used to divide Boraginaceae into either 13 (Popov 1953) or six (Riedl 1997) tribes. However, molecular phylogenies of the family are largely congruent with synthetic treatments that reduce tribal division into four tribes: Lithospermeae, Boragineae, Echiochileae and Cynoglosseae s.1. (Långström \& Chase 2002, Långström \& Oxelman 2003, Weigend et al. 2010, Nazaire \& Hufford 2012, Weigend et al. 2013, Cohen 2014). The three first tribes are each supported by autoapomorphic carpological characters: Echiochileae is characterized by a basal or submedial attachment scar and a flat to pyramidal gynobase (Långström \& Chase 2002); Lithospermeae mostly present ovoid, keeled, slightly compressed and strongly incurved nutlets with a broad basal attachment scar and a flat gynobase (Långström \& Chase 2002, Weigend et al. 2010); and Boragineae is basally attached with planar gynobase and basal annulus surrounding the scar (Hilger et al. 2004). The fourth tribe (Cynoglosseae s.1.), recognized based on molecular phylogenetics, includes a set of morphologically heterogeneous subtribes, showing the widest variety of nutlet morphology and ornamentation, including deeply dentate margins, glochidia, papillae or even surface completely smooth, and gynophore configuration from nearly flat to pyramidal. Some genera also have a more or less thickened wing. The most recent phylogenetic reconstructions (Cohen 2014; Weigend et al. 2013) recovered six well-supported major groups within Cynoglosseae s.1.: Trichodesmeae, Eritrichieae, Myosotideae, Omphalodes s.s., Mertensia clade, and Cynoglosseae s.s. This latter comprises Cynoglossum Linnaeus (1753:134) and related genera (e.g. Paracaryum Boissier (1849: 128), Rindera Pallas (1771: 486), Solenanthus Ledebour (1829: 8) and Trachelanthus Kunze (1850: 665)), several East Asian genera (e.g. Bothriospermum Bunge (1831: 47), Microula Bentham (1876: 853)), and the taxa previously considered within the subtribe Cryptanthinae. 


\section{Conclusions}

The phylogenetic reconstructions of our study, coupled with morphological characters of the nutlet, help us to propose a more natural classification of Omphalodes species. The inclusion of 14 of the 29 recognized species of Omphalodes in our phylogenetic study, clearly supports the polyphyly of the genus. Indeed, we found three independent lineages, which were consistent with results from recent publications. The morphological nutlet differences herein found provided further support for the three lineages of Omphalodes. In addition, vegetative and reproductive (inflorescence, pollen ornamentation) characters used in previous taxonomic treatments give solid grounds to recognise three genera, two of them newly proposed: Memoremea and Nihon. Despite the considerable sampling effort made for this study, additional investigations are needed to infer phylogenetic relationships of all the species of Omphalodes from North America and within Nihon. Our study has also provided an extended phylogenetic reconstruction of Boraginaceae s.s., especially tribe Cynoglosseae s.l., which also needs further sample of species and DNA sequencing regions.

\section{Acknowledgements}

First of all, we want to thank the detailed editing provided by editor (Mark Carine), as well as the two reviewers for helpful comments and suggestions. In addition we would like to thank those botanists that provided plant material, particularly Svetlana Ovchinnikova (Central Siberian Botanical Garden), PB Heenan (Allan Herbarium) and Juan Carlos Zamora (Royal Botanic Garden of Madrid), as well as the lab and SEM technicians Emilio Cano and Yolanda Ruiz from Real Jardín Botánico (Madrid) and Alberto Jorge García from the Museo de Ciencias Naturales (Madrid). We would also appreciate the following herbaria for providing loans: Royal Botanic Garden of Madrid (MA), Systematische Botanik Herbarium (MSB), Botanische Staatssammlung München (M), Herbarium of the Arnold Arboretum (A), Rancho Santa Ana Botanic Garden (RSA), Makino Botanical Garden (MBK), National Herbarium of Victoria (MEL), State Herbarium of South Australia (AD), Naturhistorisches Museum Wien (W), Natural History Museum of Florencia (FI), Missouri Botanical Garden (MO). Nomenclature discussion and recommendations from J.C. Zamora, A. Herrero, F. Muñoz-Garmendia, L. Parra and W. Greuter were kindly given. Finally, we would like to thank the support received by Sara Martín Hernanz, Mario Fernández-Mazuecos, Irene Villa, and the researchers of the Department of Botany, University of Pablo de Olavide (Seville). This study is part of the project titled "Do all endangered species hold the same value?: origin and conservation of living fossils of flowering plants endemic to Spain", which has been funded by the Fundación General CSIC and the Banco Santander (universidades).

\section{References}

Allan, H.H. (1961) Boraginaceae. In: Allan, H.H. (Ed.) Flora of New Zealand, 1. P.D. Hasselberg Government Printer, Wellington, pp. 806-833.

Al-Shehbaz, I.A. (1991) The genera of Boraginaceae, the southeastern United States. Journal of the Arnold Arboretum 1: 1-69.

Baillon, H. (1890) Boraginacées. In: Baillon, H. (Ed.) Histoire des Plantes Librairie Hatchette and Cie, Paris, 10: 402 pp.

Bentham G. (1876) Boragineae. In: Bentham G, Hooker JD, (Eds.) Genera plantarum 2. London: Reeve \& Co., pp. $832-865$.

Brand, A. (1921) Borraginaceae-Borraginoideae Cynoglossea. In: Engler. A. (Ed.) Das Pflanzenreich, 4(252). Verlag von Wilhelm Engelmann: Leipzig. 183 pp.

Boissier, E. (1844) Diagnoses plantarum orientalium novarum. Leipzig \& Paris. Ser. 1, vol. 4.86 pp.

Boissier, E. (1849) Diagnoses plantarum orientalium novarum Paris. Ser. 1, vol. 11. 136 pp.

Boissier, E. (1879) Flora Orientalis : sive, Enumeratio plantarum in Oriente a Graecia et Aegypto ad Indiae fines hucusque observatarum. Basileae: H. Georg. vol. 4, 1276 pp.

http://dx.doi.org/10.5962/bhl.title.20323

Bunge, A.A. (1831) Enumeratio plantarum, quas in China boreali collegit Dr Al. Bunge. Anno 1831. - Preprint 73 pp., without date and place. http://dx.doi.org/10.5962/bhl.title.41483

Cohen, J.I. (2014) A phylogenetic analysis of morphological and molecular characters of Boraginaceae: evolutionary relationships, taxonomy, and patterns of character evolution. Cladistics 30(2): 139-169.

http://dx.doi.org/10.1111/cla.12036

Davis, P.H. (Ed.) (1978) Flora of Turkey and the East Aegean Islands. 6. Edinburgh University Press, Edinburgh, 825 pp. 
De Candolle, A.P. (1846) Prodromus systematis naturalis regni vegetabilis. 10. Victoris Masson, Paris, 679 pp. http://dx.doi.org/10.5962/bhl.title.286

Druce, G.C. (1917) The Botanical society and exchange of British Isles 4(6). Report for 1916. T. Bruncle \& Co., Market Place, Abroath. pp. 601-653.

Drummond, A.J., Ashton, B., Buxton, S., Cheung, M., Cooper, A., Duran, C., Field, M., Heled, J., Kearse, M., Markowitz, S., Moir, R., Stones-Havas, S., Sturrock, S., Thierer, T. \& Wilson, A. (2011) Geneious v5.1.7. Biomatters. Available from: http://www.geneious. $\mathrm{com} /$ (accessed 10 July, 2013).

Euro+Med (2006-) Euro+Med PlantBase-the information resource for Euro-Mediterranean plant diversity. Version 2011.1. Botanic Garden and Botanical Museum Berlin-Dahlem, Germany. Available from: http://ww2.bgbm.org/EuroPlusMed/ (accessed 10 July 2013).

Fernández, I. \& Talavera, S. (2012) Omphalodes Mill. In: Talavera, S., Andrés, C., Arista, M., Fernández Piedra, M.P., Gallego, M.J., Ortiz, P.L., Romero Zarco, C., Salgueiro, F.J., Silvestre, S. \& Quintanar, A. (Eds.) Flora iberica 11. Real Jardín Botánico, CSIC, Madrid, pp. 471-479.

Franchet, A.R. \& Savatier, P.A.L. (1879) Enumeratio Plantarum in Japonia Sponte Crescentium. Parisiis, Apud F.Savi Bibliopolam. vol. $2,789 \mathrm{pp}$. http://dx.doi.org/10.5962/bhl.title.75

Ge-ling, Z., Riedl, H. \& Kamelin, R. (1995) Boraginaceae. In: Wu, Z.Y., Raven, P.H. (Eds.) Flora of China. Science Press and Missouri Botanical Garden Press, Beijing and St. Louis, pp. 329-427.

Gray, A. (1876) Miscellaneous Botanical Contributions. In: John Wilson (Ed.) Proceedings of the American Academy of Arts and Sciences. Boston. vol. 11, pp. $71-104$.

Gürke, M. (1893) Borraginaceae (Asperifoliaceae). In: Engler, A., Prantl, K. (Eds.) Die Natürlichen Pflanzenfamilien. W. Engelmann, Leipzig, pp. 71-131.

Haenke, T. (1788) Observationes Botaniche. In: Jacquin, N.J. (Ed.) Collectanea ad Botanicam, Chemiam, et Historiam Naturalem, Spectantia, Cumfiguris. Vindobonae, Ex officina Wappleriana. vol. 2, pp. 3-96.

Hance, H.F. (1862) Manipulus Plantarum Novarum Potissime Chinesium. Annales des Sciences Naturelles; Botanique, sér. 4, 18: $217-238$.

Hasenstab-Lehman, K.E. \& Simpson, M.G. (2012) Cat's eyes and popcorn flowers: phylogenetic systematics of the genus Cryptantha s.1. (Boraginaceae). Systematic Botany 37: 738-757. http://dx.doi.org/10.1600/036364412X648706

Heenan, P.B., Mitchell, A.D., de Lange, P.J., Keeling, J \& Paterson, A.M. (2011) Late-Cenozoic origin and diversification of Chatham Islands endemic plant species revealed by analyses of DNA sequence data. New Zealand Journal of Botany 48(2): 83-136. http://dx.doi.org/10.1080/0028825x.2010.494337

Hemsley, W.B. (1882) Boragineae. In: Godman, F.D. \& Slavin, O. (Eds.) Biologia Centrali-Americani; or, Contributions to the Knowledge of the Fauna and Flora of Mexico and Central America. Botany. London. vol. 2 pp. 366-381.

Higgins, L.C. (1976) Two new species from the Chihuahuan Desert. Phytologia 33(6): 411-413.

Hilger, H.H., F. Selvi, A. Papini, \& M. Bigazzi, M. (2004) Molecular systematics of Boraginaceae tribe Boragineae based on ITS1 and trnL sequences, with special reference to Anchusa s. 1. Annals of Botany 94: 201-212.

http://dx.doi.org/10.1093/aob/mch132

Hoffmannsegg, J.C. \& Link, J.H.F. (1811) Flore portugaise ou Description de toutes les plantes qui croissent naturellement en Portugal. Berlin: Amelang. vol. 1, 458 pp.

Hu, H.H. (1936) Sinojohnstonia, a new genus of Boraginaceae from Szechuan. Bulletin of the Fan Memorial Institute of Biology; Botany. Peiping. 7(5): 201-205.

Jeanes, J.A. (1999) Boraginaceae. In: Walsh, N.G. \& Entwisle, T.J. (Eds.) Flora of Victoria, 4. Inkata Press, Melbourne, pp. $387-411$.

Jobb, G., Haeseler, A. \& Strimmer K. (2004) TREEFINDER: a powerful graphical analysis environment for molecular phylogenetics. BMC Evolutionary Biology 4: 18.

Jobb, G. (2007) TREEFINDER version of February 2007. Munich, Germany. Distributed by the author at www.treefinder.de (Accessed December 2012).

Johnston, I.M. (1924) Studies in the Boraginaceae II. 1. A synopsis of the American native and immigrant Borages of the subfamily Boraginoideae. Contributions from the Gray Herbarium of Harvard University 70: 3-55.

Johnston, I.M. (1935) Studies in the Boraginaceae XI, 16. Journal of Arnold Arboretum 2: 145-205.

Ka, M. (1965) Boraginaceae. In: Meyer, F.G. \& Walker, E.H. (Eds) Flora of Japan by Jisaburo Ohwi.Smithsonian Institution, Washington D.C., pp. $755-762$.

Kadota, Y. (2009) Omphalodes akiensis (Boraginaceae), a new species from Hiroshima prefecture, western Japan. Journal of Japanese Botany 84: 342-349. 
Katoh, K., Misawa, K., Kuma, K. \& Miyata, T. (2002) MAFFT: a novel method for rapid multiple sequence alignment based on fast Fourier transform. Nucleic Acids Research 30: 3059-3066. http://dx.doi.org/10.1093/nar/gkf436

Kolakovsky, A.A. (1948) Omphalodes kusnetzovii Zametki po Sistematike i Geografii Rastenii 14: 62.

Kumar, S., Skjæveland, A., Orr, R.J.S., Enger, P., Ruden, T., Mevik, BM., Burki, F., Botnen, A. \& Shalchian-Tabrizi, K. (2009) AIR: A batch-oriented web program package for construction of supermatrices ready for phylogenomic analyses. BMC Bioinformatics, 10: 357. http://dx.doi.org/10.1186/1471-2105-10-357

Kunze, G. (1850) Borraginearum novum genus proposuit. Botanische Zeitung. Berlin. 8(37): 665-680.

Långström, E. \& Chase, M.W. (2002) Tribes of Boraginoideae (Boraginaceae) and placement of Antiphytum, Echiochilon, Ogastemma and Sericostoma: a phylogenetic analysis based on atpB plastid DNA sequence data. Plant Systematics and Evolution 234: $137-153$.

Långström, E. \& Oxelman, B. (2003) Phylogeny of Echiochilon (Echiochileae, Boraginaceae) based on ITS sequences and morphology. Taxon 52: 725-735. http://dx.doi.org/10.2307/3647347

Ledebour, C.F. von (1829) Icones Plantarum Novarum vel Imperfecte Cognitarum Floram Rossicam, Imprimis Altaicam, Illustrantes. Rigai, Apud I. Deubner. Vol. 8, 24 pp. http://dx.doi.org/10.5962/bhl.title.46626

Linnaeus, C. (1753) Species Plantarum 2. Laurentii Salvii, Stockholmiae, 1200 pp.

Maximowicz, I. (1859) Primitiae Florae Amurensis Primitiae Florae Amurensis. St. Petersburg. Buchdruckerei der Kaiserlichen Akademie der Wissenschaften. 504 pp.

Maximowicz, I. (1872) Diagnoses plantarum novarum Japoniae et Mandshuriae. Bulletin de l'Academie Imperiale des Sciences de SaintPétersbourg. St. Petersburg 17(3) 417: 456.

Miller, P. (1754) Gardeners Dictionary. 2, $4^{\text {th }}$ Ed. Folio Edition. London.

Moench, C. (1794) Methodus plantas horti botanici et agri Marburgensis a staminum situ describendi. 2 Marburgui Cattorum, Marburg, 780 pp. http://dx.doi.org/10.5962/bhl.title.304

Mozaffar, M.K., Osaloo, S.K., Oskoueiyan, R., Saffar, K.N. \& Amirahmadi, A. (2013) Tribe Eritricheae (Boraginaceae s.str.) in West Asia: a molecular phylogenetic perspective. Plant Systematics and Evolution 299: 197-208. http://dx.doi.org/10.1007/s00606-012-0715-4

Nakai, T. (1949) Omphalodes laevisperma. Journal of Japanese Botany. [Shokubutsu Kenkyu Zasshi]. Tokyo. $23: 17$.

Nasir, Y.J. (1989) Boraginaceae. In: Ali, S.I., Nasir, Y.J. (Eds.) Flora of Pakistan, No. 191. Pakistan Agricultural Research Council, Islamabad, pp. 1-200.

Nazaire, M. \& Hufford, L. (2012) A Broad Phylogenetic Analysis of Boraginaceae: Implications for the Relationships of Mertensia. Systematic Botany 37(3): 758-783. http://dx.doi.org/10.1600/036364412X648715

Nesom, G.L. (2013) A third species of Mimophytum s. str. and three new species of Omphalodes (Boraginaceae) from North America. Phytoneuron 64: 1-23. Published 13 September 2013.

Ohwi, J (1956) Notes of some Plants from Japan and its neighbours. Bulletin of the National Science Museum, Tokyo. 3(39): 98-101.

Pallas, P.S. (1771) Reise durch verschiedene Provinzen des Russischen Reichs. St. Petersburg: gedruckt bey der Kayserlichen Academie der Wissenschaften. pt. 1. 504 pp.

Pereira Coutinho, A.P., Castro, S., Carbajal, R., Ortiz, S. \& Serrano, M. (2012) Pollen morphology of the genus Omphalodes Mill. (Cynoglosseae, Boraginaceae). Grana 51: 194-205.

http://dx.doi.org/10.1080/00173134.2012.665943

Popov, M.G. (1953) Boraginaceae. In: Shishkin, B.K., Bobrov, E. (Eds.) Flora U.S.S.R: Tubiflorae. Izdatel'stvo Akademii Nauk SSSR, Moskva, Leningrad, pp. 98-715.

Posada, D. (2008) jModelTest: Phylogenetic Model Averaging. Molecular Biology and evolution. 25 (7): 1253 -1256. http://dx.doi.org/10.1093/molbev/msn083

Riedl, H. (1967) Boraginaceae. In: Rechinger, K.H. (Ed.) Flora Iranica. Akademische Druck- und Verlagsanstalt, Graz, pp. 1-281.

Riedl, H. (1997) Boraginaceae. In: Kalkman, C., Kirkup, D.W., Nooteboom, H.P., Stevens, P.F. \& de Wilde, W.J.J.O. (Eds.) Flora Malesiana, 13, Series I - Seed Plants. Rijksherbarium/Hortus Botanicus, Leiden, pp. 43-144.

Riedl, H. \& Edwards, S. (2006) Boraginaceae. In: Hedberg, I., Kelbessa, E., Edwards, S., Demissew, S., \& Persson, E. (Eds.) Flora of Ethiopia and Eritrea, 5. National Herbarium, Biology Department, Science Faculty, Addis Ababa University. pp. 64-102.

Roemer, J.J. \& Schultes, J.A. (1819) Systema vegetabilium. 4, $15^{\text {th }}$ Ed, J.G. Cottae, Stuttgard, 888 pp.

Ronquist, F. \& Huelsenbeck, J.P. (2003) MrBayes 3: Bayesian phylogenetic inference under mixed models. Bioinformatics 19: $1572-1574$. http://dx.doi.org/10.1093/bioinformatics/btg180 
Roth, A. W. (1797) Catalecta Botanica. Lipsiae, Bibliopolio. vol. 1. 244 pp.

Roth, A.W. (1827) Enumeratio Plantarum Phanerogamarum in Germania sponte nascentium. Pars prima, sectio prior. 1, J. F. Gleditsch, Oxford, $1015 \mathrm{pp}$.

Schrank, P.F. von (1812) Omphalodes eine wiederhergeftellte Gattung. Denkschriften der Königlichen Akademie der Wissenschaften zu München 3: 217-222.

Schultz, C.F. (1806) Prodromus Florae Stargardiensis. Berolini, Sumtibus C.F.E.Spaethen. 530 pp.

Shimodaira, H. (2002) An Approximately Unbiased Test of Phylogenetic Tree Selection Systematic Biology 51(3): 492-508. http://dx.doi.org/10.1080/10635150290069913

Sommier, S. \& Levier, E. (1892) Decas Plantarum Novarum Caucasi. Acta Horti Petropolitani. St. Petersburg. 12(5): 151-159.

Stevens, P. F. (2001 onwards). Angiosperm Phylogeny Website. Version 2012. 7. University of Missouri, St Louis, and Missouri Botanical Garden U.S. Available from: http://www.mobot.org/MOBOT/research/APweb/ (accessed: 10 July 2013).

Strid, A. \& Tan, K. (2005) A new species of Omphalodes (Boraginaceae) from Southeast Peloponnese, Greece. Phytologia balcanica 11 (1): 69-72.

Sun, Y., Skinner, D.Z., Liang, G. H. \& Hulbert, S. H. (1994) Phylogenetic analysis of Sorghum and related taxa using internal transcribed spacers of nuclear ribosomal DNA. Theoretical and Applied Genetics 89: 26-32. http://dx.doi.org/10.1007/bf00226978

Sweet, R. (1826) Sweet's Hortus Britannicus: or, A catalogue of plants cultivated in the gradens of Great Britain. James Ridgway. London. 492 pp. http://dx.doi.org/10.5962/bhl.title.43792

Taberlet, P., Gielly, L., Pautou, G., Bouvet, J. (1991) Universal primers for amplification of three non-coding regions of chloroplast DNA. Plant Molecular Biology 17: 1105-1109. http://dx.doi.org/10.1007/bf00037152

Talavera, S., Andrés, C., Arista, M., Fernández Piedra, M.P., Gallego, M.J., Ortiz, P.L., Romero Zarco, C., Salgueiro, F.J., Silvestre, S. \& Quintanar, A. (Eds.) (2012) Boraginaceae. In: Castroviejo, S., Aedo, C., Laínz, M., Muñoz Garmendia, F., Nieto Feliner, G., Paiva, J. \& Benedí, C. (Eds.) Flora Iberica, 11. Real Jardín Botánico. CSIC. pp. $324-532$.

Thulin, M. \& Warfa, A.M. (2006) Boraginaceae. In: Thulin, M. (Ed.) Flora of Somalia, 3. Royal Botanic Gardens, Kew, pp. 31-60.

Thunberg, C. (1784) Cynoglossum japonicum. In: Linné, C. von, Dieterich, J.C. \& Murray, J.A. (Eds.) Systema Vegetabilium: secundum classes ordines genera species cum characteribus et differentiis. Editio decima quarta. Gottingae: Typis et impensis Jo. Christ. Dieterich 1004 pp.

Toelken, H.R. (1986) Boraginaceae. In: Jessop, J.P \& Toelken, H.R (Eds.) Flora of South Australia, Part III, Polemoniaceae-Compositae. South Australian Govt. Printing Division, pp. 1146-1173.

Tutin, T.G., Heywood, V.H., Burges, N.A., Moore, D.M., Valentine, D.H., Walters, S.M. \& Webb, D.A. (Eds.) (1972) Flora Europaea. Diapensiaceae to Myoporaceae, 3. Cambridge University Press, Cambridge. pp. 83-122.

Valdés, B. (2004) The Euro+Med treatment of Boraginaceae. Willdenowia 34: 59-61. http://dx.doi.org/10.3372/wi34.34103

van Ooststroom, S.J., Reichgelt, TH.J., Karstens, W.K.H., De Jonhgh, S.E. \& Stafleu, F.A.(Eds.) (1961) Flora Neerlandica, PlumbaginaceaeBoraginaceae, 4 (1). Amsterdam Koninklijke Nederlandse Botanische Vereniging, 141 pp.

Wallroth, K.F. (1822) Schedulae Criticae de Plantis Florae Halensis Selectis. Corollarium novum ad C. Sprengelii Floram halensem. Accedunt generum quorundam specierumque omnium definitiones novae, excursus in stirpes difficiliores. Tom. I. Phanerogamia. Halae. vol. 1, 516 pp.

Weigend, M., Gottschling, M., Selvi, F. \& Hilger, H.H. (2010) Fossil and extant Western Hemisphere Boragineae, and the polyphyly of “Trigonotideae" Riedl (Boraginaceae: Boraginoideae). Systematic Botany 35: 409-419. http://dx.doi.org/10.1600/036364410791638423

Weigend, M., Luebert, F., Selvi, F., Brokamp, G. \& Hilger, H.H. (2013) Multiple origins for Hound's tongues (Cynoglossum L.) and Navel seeds (Omphalodes Mill.) - The phylogeny of the borage family (Boraginaceae s.str.). Molecular Phylogenetics and Evolution 68: 604-618. http://dx.doi.org/10.1016/j.ympev.2013.04.009

White, T.J., Bruns, T., Lee, S. \& Taylor, J. (1990) Amplification and direct sequencing of fungal ribosomal genes for phylogenetics. In: Innis, M., Gelfand, D., Sninsky, J., White, T. (Eds.) PCR Protocols: A Guide to Methods and Applications. Academic Press, New York, pp. 315-322.

Yamazaki, T. (1993) Boraginaceae. In: Iwatsuki, K., Yamazaki, T., Boufford, D.I. \& Ohba, H. (Eds.) Flora of Japan. 3a. Kodansha, Tokyo, pp. 244-258. 